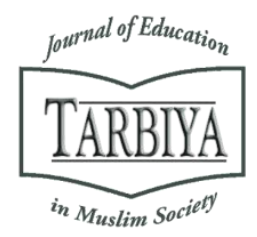

Available online at TARBIYA: Journal of Education in Muslim Society Website:

http://journal.uinjkt.ac.id/index.php/tarbiya

TARBIYA: Journal of Education in Muslim Society, 4(2), 2017, 224-231

\title{
EDUCATION IN INDONESIA' S BORDER REGIONS
}

\author{
Farid Wadjdy \\ Nahdatul Ulama University, East Kalimantan, Indonesia \\ E-mail: faridwadjdy15@gmail.com
}

Received: $28^{\text {th }}$ September 2017; Revised: $25^{\text {th }}$ November 2017; Accepted: $27^{\text {th }}$ December 2017

Abstract

This paper aims to figure out the government policy in education management, community participation, and accessibility in border area. The qualitative framed theory with case study approach was used as the method of this study. The results showed that government was enacting special policies in national school operational assistance, providing block grant funds, special allowances for teachers and education personnel in border areas. Participation of the community was in the form of building dormitory in mutual assistance; customary heads took the legal role of school land and cultural preservation through extracurricular activities. Implementation of education in the form of nationalism enhancement assisted by the Indonesian National Army, facilities and school infrastructure were still under the national standards, teachers and employees were not disciplined, and supervision had not functioned optimally. When the teacher had given an assignment out of the region sometimes they had to leave their teaching job for up to two weeks late due to difficult access.

Keywords: Public policy; community participation; accessibility

\begin{abstract}
Abstrak
Artikel ini bertujuan untuk meninjau kebijakan pemerintah dalam manajemen pendidikan, partisipasi masyarakat, dan aksesibilitas di daerah perbatasan. Teori yang dirumuskan secara kualitatif dengan pendekatan studi kasus digunakan sebagai metode penelitian ini. Hasil penelitian menunjukkan bahwa pemerintah memberlakukan kebijakan khusus dalam bantuan operasional sekolah nasional, menyediakan dana hibah blok, tunjangan khusus yang diperuntukan bagi guru dan tenaga kependidikan di daerah perbatasan. Partisipasi masyarakat adalah dalam bentuk membangun asrama dalam bantuan timbal balik; Kepala adat mengambil peran hukum pada ranah sekolah dan pelestarian budaya melalui kegiatan ekstrakurikuler. Pengimplementasian pendidikan dalam bentuk peningkatan nasionalisme dibantu oleh Tentara Nasional Indonesia, fasilitas dan infrastruktur sekolah masih di bawah standar nasional, guru dan karyawan yang tidak disiplin, dan pengawasan tidak berfungsi secara optimal. Ketika guru telah diberikan tugas di luar daerah, kadang-kadang mereka harus meninggalkan pekerjaan mengajar mereka hingga dua minggu lebih lama dari waktu yang ditugaskan karena akses yang tidak mudah dijangkau.
\end{abstract}

Kata kunci: Kebijakan publik; partisipasi masyarakat; aksesibilitas

How to Cite : Wadjdy, F. (2017). Education in Border Regions. TARBIYA: Journal of Education in Muslim Society, 4(2), 224-231. doi:10.15408/tjems.v4i2.6982.

Permalink/DOI: http://dx.doi.org/10.15408/tjems.v4i2.6982

TARBIYA: Journal of Education in Muslim Society, P-ISSN: 2356-1416, e-ISSN: 2442-9848

This is an open access article under CC-BY-SA license (https://creativecommons.org/licenses/by-sa/4.0/) 


\section{Introduction}

Border Area according to Law Number 43 Year 2008, is a part of the territory of the State located on the inside of the border of Indonesia with other countries, in the case of the State Territory Boundary on land, Border Area is located in the sub district. According to Law number 26 of 2007 on spatial planning, border is Regency or a City that geographically and demographically bounded directly to neighboring countries and / or the high seas (BPKP2DT, 2010: 11).

Indonesia's border is still apprehensive in many ways. Many border areas are face up to economic backwardness due to the absence of government and private programs and projects. The length of the borderline both on land and oceans is very difficult to be monitored regularly by security forces. As a result, violations of border areas, smuggling, and other illegal crossborder activities often occur. In some areas far from Indonesian government offices, people at the border actually get a lot of administrative facilities and public services from neighboring countries and it make their nationalism split. Communication and information access is also often easier to obtain from neighboring countries that have been advancing their border areas. Because it is neglected for a long time, the border area in Indonesia has been considered to have a negative international assumption. That negative image created as the result of neglecting the border area as a place of illegal logging, illegal workers, and smuggling. In addition, the lagging of development in the border region and the emergence of tensions as a result of isolation of the region, causing this area can be an entry point for the departure of terrorists who fear the international world (transnational-terrorists), Sutaat (2011: 4-5).

Most of the border areas in East Kalimantan consist of high altitudes, with altitudes of more than 1000 meters above sea level (asl), through the border with Kutai Barat and parts of Malinau which is a series of Iban mountains. Some of Malinau and Nunukan are lowland areas, with an altitude of 100 to 200 meters above sea level. Some of the border of Nunukan is the sea border, and there is a border through a small island, namely Sebatik Island. The northern part of this island is the territory of Malaysia and the southern part of this island is the territory of Indonesia. These geographical conditions are affecting the spread of population and activities in the border region becoming complex.

In general, the population of East Kalimantan is divided into two groups, namely ethnic groups of Malay and Dayak ethnic groups. Ethnic Malays live on the coast and along the banks of the river by embracing Islam. While Dayak tribe or Lundaye considered as native island of Borneo, and usually reside in hills or hinterland. The pattern of Dayak's life is following a shifting cultivation system.

The development of border areas in East Kalimantan is an integral part of the national border development. This border area in East Kalimantan has considerable potential natural resource, and is a very strategic area for the defense and security of the country. However, in general the development of border areas is still far behind compared with the development in the territory of neighboring countries. The social and economic conditions of the people living in this area are generally much lower than the socio-economic conditions of neighboring citizens. This has resulted in the emergence of various illegal activities in the border areas which are feared in the long run can lead to various social vulnerabilities. The condition of the border area of East Kalimantan with the state of Malaysia to this day is still very poor condition. Fundamental issues of development in border areas are the isolation of areas, development, and 
the quality of human resources, education, health, infrastructure and agriculture in the broad sense that impacts the development of the region on all areas of development, Patnership (2011: 6).

Nunukan Regency is adjacent to Serawak, Krayan Hulu and Krayan Hilir sub-districts, Lumbis sub-district, Pameliangan sub-district, Nunukan sub-district and west and east Sebatik sub-district. Each sub-district has dozens of small villages scattered along the border and far apart. Some villages within the sub-district only have paths, as a means of connecting through which the next village. This path length can reach ten of kilometers. Whereas the connecting access between sub-districts with the other sub-districts or with regency capitals can only be reached by pioneer aircraft, making accessibility very difficult to achieve.

BPKP2DT (Border Area Management Agency, Rural and Underdeveloped Region) (2010: 105), stated that accessibility in restricted areas is very limited not only on land and river but also on air. Several sub-districts on the border such as: Karayan, South Krayan, Kayan Hulu, Kayan Hilir, can only be accessed by aircraft from the capital District with limited capacity and frequency. Similarly, other subdistricts such as Pujungan, Long Pahangai, Long Apari, can only be reached by river transportation with high cost and high difficulty level.

Infrastructure of land, river and air transportation connecting between sub-districts and inter-districts on the border are still very limited. Some sub-districts on the border are still isolated and costly to access. Trans Kalimantan Road has not been fully realized, and partly in damaged condition. Air Transportation which is expected to be the main solution cannot be optimized because the operational cost is relatively expensive, which in turn has implications for the increase of goods price either for the basic needs of society and development cost. So far, the border community depend on neighboring countries in terms of meeting their basic needs, because it is easier to get and relatively cheaper when compared with goods originating from their own country, BPKP2DT (2010: 106).

A border area has two features in terms of its location: it lies at the periphery of its own country and is the closest area to the neighboring country. This gives rise to two features of education in a border area: an inward orientation toward the upbringing of citizens of the home nation, and an outward orientation toward the education in the neighboring country. The contrast between these orientations is more clearly apparent in the border areas than elsewhere.

BPKP2DT, which makes the grand strategy of managing the East Kalimantan border in northern isolated area by the term of $3 \mathrm{~T}$ region. The development of underdeveloped, remote, and isolated regions known as 3T (frontier, outermost and underdeveloped), in North Kalimantan, requires special treatment. This special treatment could be a boundary school, the use of information technology such as the internet or the unification of schools from primary to senior level in one location, or commonly known as an integrated school. This $3 \mathrm{~T}$ area is located in coastal areas (beach and outer islands), inland and on the border of Republic of Indonesia and Malaysia. Educational services, must reach $3 \mathrm{~T}$ to avoid a gap in the quality of human resources in north Kalimantan. This condition arise the assumption among the people around the border area that in the city is the place to obtain a good education. The village or the $3 \mathrm{~T}$ area is under-prioritized so that the stigma of lagging and isolating is becoming increasingly and difficult to dislodge for inland and border areas, BPKP2DT (2013: 6). 
Such conditions become more severe with the lack of interest of the teachers who want to teach in disadvantaged areas and borders. It is not an exaggeration if the low average level of community education in the $3 \mathrm{~T}$ area affects the human development index in North Kalimantan. It is necessary to find and establish an education service acceleration strategy in north Kalimantan, especially for people in $3 \mathrm{~T}$ area, so that the gap of human resource quality in the border becomes minimized. The intended strategy is expected to be implemented in all $3 \mathrm{~T}$ areas involving various components of communities, social organizations, government and stakeholders in East Kalimantan.

BPKP2DT (2013: 8), states that objective conditions that cannot be denied are the existence of villages with minimal population (25 to 40 heads of families only). To build schools in these locations are not efficient since the limited of students. But if there is no school then the children have to travel far to get education. As the condition in border area is difficult it makes many families decided to migrate to Malaysia and becoming migrant worker in some plantations. This condition force their children have to get education with a very long distance from their settlement in Malaysia plantation to the nearest school in Indonesia. Sometimes they cannot attend to the school when there is a cross border check points by immigration officers in the border of Malaysia Indonesia (Rosliana et al, 2015: 318). Schools with limited number of students still face problems which are; inadequate school infrastructure, lacks of textbooks, due to the difficulty of transportation and the lack of educators because many teachers who teach in border villages choose to migrate to urban areas.

Improving the quality of education at the border area is a necessity, as it is an important step to strengthen the national defense system on Indonesia's frontier through education and culture. Improving access to education across borders could remove the stigma of national political inequality on improving human and infrastructure resources and making people in border areas proud to be part of the unitary state of the Republic of Indonesia. Of course all of it becomes our responsibility to find a solution; so that education there has an equal quality to other areas of geographic location is more profitable so it will not be far behind from our own neighbor country of Malaysia. Therefore, to obtain a comprehensive description of educational issues in the border areas, this paper attempts to provide an overview of the education in the northern border area of Kalimantan.

\section{Method}

Shank (2002) defines qualitative research as a form of systematic empirical inquiry into meaning. By systematic it means "planned, ordered and public", following rules agreed upon by members of the qualitative research community. By empirical, it means that this type of inquiry is grounded in the world of experience. Inquiry into meaning says researchers try to understand how others make sense of their experience. This means that qualitative researchers study things in their natural settings, attempting to make sense of, or to interpret, phenomena in terms of the meanings people bring to them.

Since the focus of this study was on the analysis of the education in border area without any experimental or manipulated settings involved, therefore, the design of this study was qualitative design using case study method which is a research about a unity of system. Case studies are research directed to collect data, take meaning, and gain an understanding of the case. Djunaidi Ghony (2016: 62) stated that the case does not represent the population at all and is not intended to derive conclusions from the 
population. The subjects of this study were four junior high schools namely SMPN 1, SMPN 2, and SMPN 3serta SMPN 4 Krayan.

The data that collected in this research were check list of observation, and interview. For data collection technique, the observation and interview were used. Data from observation would be functioned as primary data and data from interview was functioned as supporting data. Since this study would like to figure out the education in border area of north Kalimantan, observation was considered the effective way to support this step. The observation was conducted to the each class of the research subjects to get more obvious point of view. For the sake of gathering more information during the observation process, the field notes were also taken. To get information from the teachers and students about the researcher's findings from the observation, the interview was chosen as the cross-checking data.

In data reduction, the data from observation, and interview were selected, focused, simplified, made an abstract, and transformed. At the second step, the data were displayed by using the list of problem and government policy related to education in border area and transcription of the interview and give explanation about them. In the last step, conclusion drawing and verification, the conclusion and verified through the result on data display were made.

In this study data triangulation was used using more than one source to gather data. Observation was conducted to gather the obvious phenomenon of education in border area especially about the problem, government policy, community involvement and accessibility related to this issue. Interview with some informants was used to strengthen and confirm the result of observation.

\section{Results and Discussion}

\section{Education policy}

School Operational Assistance Programme (BOS) is a government program that provides non-personnel funding to elementary and secondary educational units as a part of the implementation of the nine years of compulsory education program. BOS prioritizes nonpersonnel operational costs, although it is possible for funds to be used for activities categorized as personnel and investment costs. The general purpose of $\mathrm{BOS}$ is to ease a community's burden to fund education in the context of meeting the nine years of compulsory education program. BOS targets all students at elementary school/madrasah ibtidaiyah (MI) and middle school/madrasah tsanawiyah (MTs), including open secondary schools and independent activity study centers (Pusat Kegiatan Belajar Mandiri, or PKBM) organised by communities, both public and private in all provinces across Indonesia. BOS funds received by schools during the 2012 fiscal year are calculated based on numbers of students, under following provisions: a) Elementary Schools (SD/SDLB): Rp.580,000-/student/annually; b) Junior High schools (SMP/SMPLB/ SMPT): Rp. 710,000-/student/annually

The distribution of BOS, at junior high schools in Krayan sub-district was as follows; (a) Krayan District BOS policy making for junior high school with a total number of 19 students accumulated to 120 students, (b) There was solar cell aid to operate the computer in order to facilitate the completion of the accountability report.

Local government efforts to equalize development in the area 3 (Krayan Sub-district) to be equal to regions 1 and 2 of Nunukan and Sebatik were as follows; (a) teachers who had achievement were rewarded a laptop, (b). The limitations of teachers on the border were 
overcome by cooperating with several universities, through teaching bachelor movement in frontier, remote, and backward areas and 36 volunteers involved in this program, (c) Teacher training centered in sub-districts.

Issues in Education Management in Krayan Sub-district were as follows; (a) the number of villages spread over 78 villages with great distances and difficult accessibility, (b) each village could be reached in 2 to 3 hours on foot, (c) Liability report (LPJ) of BOSNAS was not arranged accord to school work plan and budget (d) improper school facilities and infrastructure, rather than the minimum standards to be met, (e) lack of educators who had conformity to their educational background, ( $f$ ) the fund of block grant could not be functioned in accordance with the school's work plan and budget. (h) school development still concentrated only in Sebatik and Nunukan areas, (i) school committees in meetings and coordination, proposing to be honored by the government , (j) Teacher Performance Assessment and Sustainable Culture Development had not been able to apply, it only would be informed to the teacher, (k) Krayan people who had completed education in the city did not want to go back to the area of origin to work, although $70 \%$ more people were already undergraduate, (l) difficulty to access DAPODIK, because the BTS tower was limited, and hindered the mountains and could only be accessed at some point only, (m) $90 \%$ of teachers had a tradition of spending their time in night club, so they came late to school.

The efforts made by the Education Office and the District Government of Nunukan in solving the problem were; (a) Efforts to overcome these problems include; for students from distant villages, a dormitory was built, to shorten the distance between schools and learners, (b) for the Accountability Report (LPJ) of BOS Education Office delegated to the task implementation unit (UPT), to undertake monitoring and evaluation in cooperation with PGRI and Board of Education, (c) before opening a certain department, a school should to obtain approval from the UPT, which was then issued the approval by the District Education Office, (d) granted block grant funds for education quality improvement program (e) allocated the appointment of educators and educational staff proportionally, (f) Standard General Cost (SBU) functioned in accordance with the price in Krayan, although the provisions made from the center cannot be treated because the price was very high, e.g. cement one sack was Rp. $1,000,000$ to $1,200,000$, technical guidance for $6 \mathrm{RKB}$ could only be made $3 \mathrm{RKB}$, budget revision was known by Public Works Department of Nunukan Regency, (g) Krayan with remote area and accessibility was difficult, hence needed to add budget and move priority from region 2 to region 3, (h) provided socialization of the functions and roles of school committees, including traditional leaders who had already been the implementers of the legality of school lands, (i) formed a team which already trained to disseminate and train principals and Teacher Performance Assessment and Sustainable Culture Development (PKG and $\mathrm{PKB}$ ) team in sub district level, (j) provided special border area allowance for teachers and educational staff, $(\mathrm{k})$ gathered teachers from various villages in one place where the internet was accessible, that took time approximately one week, for completion of duties, (l) Monitored the implementation of education in cooperation with the Board of Education and PGRI.

\section{Participation of Community in Education Management}

The findings related to the community participation in the management of education such as; (a) The role of the committee and the parents only provided the assistance of personnel if necessary, for example in conducting school 
mutual cooperation and bookkeeping report cards, (b) Parents' attendance was minimal only 10 people out of 200 were invited due to a public perception of free tuition fee school, (c) because of difficult Access and long distant, then the community built a dormitory in mutual cooperation to accommodate students to stay from Monday to Saturday, and Sunday afternoon students have returned to the dorm again, ( d) Provided food aids to the students especially for those who live far away and living in shelter homes, (e) Participation of parents was twice a year especially in student report bookkeeping, (f) traditional leaders as community leaders played a role in customizing land and used for schools, (g) The role of custom was the preservation of culture through art galleries in the framework of extracurricular activities.

The result of the research showed that in this case the parents of the students as members of the school committee had not maximized their participation in education management. It only reflected in the participation of the mutual cooperation to clean up the school, and participated in the student book reporting meeting. While function and other roles were found was the role of community leaders as mediator of education in school.

\section{Education in Border Areas}

The findings of the educational process in Krayan were; (a) due to TNI soldiers helped to teach in schools there were improving nationalism of the students, (b) BOSNAS assistance was used for photocopy of textbooks and the latest textbooks received from government was in 2012, (c) the management of BOSNAS had not yet had the staff from civil servants, technical guidelines and socialization were required for all schools, (d) lack of school facilities and infrastructure and it was still below of national education standards, (e) there were teachers and employees who had lack of discipline in performing their duties, and supervision had not functioned optimally; the role of supervisor was not maximized. Nunukan District is too far from the capital city, so there was no reward and punishment from the supervision process.

The Office of Education needed to make a breakthrough such as; the school operational fund could be receive in punctual and appropriate manner, increased the guidance of teachers and employees more intensively, and enhanced the role and function of supervisors effectively and efficiently according to the characteristics of the border area.

\section{Accessibility}

Several findings from research on accessibility in Krayan sub-district were as follows; (a) as a result of difficult accessibility that hindered by mountains and rivers the people around Krayan had different languages, (b) after had given an assignment out of the region, teachers often late for 2 weeks due to no flight and no aircraft to fly back to Krayan , (c) because of the geographical condition some students live far away from school and must be reached on foot, so a shelter was required, (d) accessibility of schools in Krayan had no internet network.

Indeed, the government needed to make appropriate planning with the priority needs of the community, especially transportation, educational facilities, internet and electricity networks as well as subsidized flights to the border areas.

\section{Conclusion}

The role of the government in implementing the policy that is considered to be the determinant will ends up the education 
performance of the border area especially in Krayan Sub-district of Nunukan Regency in making the decision about education. Local government policies on education related to teachers, education funding, to educational facilities in the border areas have been pursued with various efforts. By understanding the idea of policy implementation, the role of the government in implementing the policy that is considered to be the determinant of the gate of the state will support the education performance of the Krayan Sub-district of Nunukan Regency in making the decision about education. Community participation in border areas is very helpful for local government policies to build border areas. The participation of the community can be in the form of giving consideration, support, giving control of education implementation and as a liaison between the community and local government in particular.

Participation of the community still emphasized on physical support such as to build a dormitory in mutual cooperation to accommodate students to stay and provided food aids to the students especially for those who live far away and living in shelter homes. Community and traditional leader need to be involved in the establishment and implementation of educational units that could be implemented in all types and levels of formal education from planning, development and evaluation of education implementation in border areas

\section{References}

BPKP2DT. 2013. Guru Perbatasan Belum Sebuah Pilihan. Buletin Kawasan Perbatasan Kalimantan Timur. 4 (2).

BPKP2DT. 2010. Grand Strategi Pengelolahan Perbatasan Kalimantan Timur. Jakarta.

Ghony, D. \& Almansyur, F. 2016. Metode Penelitian Kualitatif. Yogyakarta: Ar Ruzz Media

Kementerian Pendidikan Nasional. 2009. Rencana Strategis Kementerian Pendidikan Nasional 2009-2014. Jakarta.

Rosliana, et.al. 2015. Manajemen Perbatasan Fokus Inovasi Pendidikan di Perbatasan Kalimantan Utara. Jurnal Borneo Administrator 11(3), 316-339.

Shank, G. (2002). Qualitative Research. A Personal Skills Aproach. New Jersey: Merril Prentice Hall.

Sutaat. 2012. Pemberdayaan Masyarakat Daerah Perbatasan Antar Negara. Sosiokonsepsia, 17 (01): 52-71. 